\title{
DUGAAN UPWELLING BERDASARKAN ANALISIS KOMPARATIF CITRA SEBARAN SUHU PERMUKAAN LAUT DAN KLOROFIL-A DI TELUK TOMINI
}

\author{
Khairul Amri"), Suwarso"), dan Herlisman*)
}

\begin{abstract}
ABSTRAK
Penelitian dugaan upwelling di perairan Teluk Tomini berdasarkan pada analisis komparatif citra satelit telah dilakukan pada 2003 sampai dengan 2004. Penelitian ini bertujuan mengkaji dugaan terjadinya upwelling di perairan Teluk Tomini berdasarkan pada analisis citra SPL dan citra klorofil-a hasil pantauan satelit berbeda selama 1 tahun pengamatan yang dipadukan dengan hasil pengukuran in situ (suhu, salinitas, dan kelimpahan plankton) sebagai data pembanding. Hasil menunjukkan bahwa upwelling terjadi pada musim timur (puncak pada bulan Juli sampai dengan Agustus), intensitas tertinggi ditemukan di sekitar mulut teluk bagian selatan. Pergerakkan massa air northern lower water di kedalaman $150 \mathrm{~m}$ yang mendesak massa air Laut Maluku di mulut teluk berbenturan dengan daerah tubir diduga memicu terjadinya proses tersebut. Pada saat upwelling terjadi penurunan SPL berkisar 27,5 sampai dengan $29,0^{\circ} \mathrm{C}$, sedangkan kandungan klororil-a menunjukkan peningkatan yang tajam $\left(0,8\right.$ sampai dengan $\left.1,25 \mathrm{mg} \mathrm{m}^{-3}\right)$. Hasil pengukuran in situ terhadap suhu permukaan laut di lokasi upwelling menunjukkan nilainya lebih rendah berkisar antara 26,2 sampai dengan $27,0^{\circ} \mathrm{C}$, suhu yang rendah diikuti oleh peningkatan salinitas ( 34,0 sampai dengan $35,5 \%$ ) yang mengindikasikan kenaikan massa air dalam ke permukaan memperkuat dugaan tersebut. Hasil pengarnbilan contoh plankton di daerah penelitian khususnya di sekitar lahan upwelling menunjukkan peningkatan konsentrasi dengan kelimpahan berkisar 80.010 sampai dengan $1.082 .520 \mathrm{sel} \mathrm{m}^{-3}$
\end{abstract}

ABSTRACT: Upwelling supposition based on comparative analyze of sea surface temperatur and chlorophyll-a images in Tomini Bay. By: Khairul Amri, Suwarso, and Herlisman

Study on upwelling supposition in Tomini Bay based on comparative analyze of satellite images was carried out in 2003-2004. The aim of this research is to study the upwelling phenomena based on sea surface temperature and chlorophyll-a images compared with in situ measurement data (temperature, salinity, and abundance of plankton) as complement. One year long data were examined for this study sea surface temperature and chlorophyll-a images of satellite sensors data including. The result shows that upwelling occurred during east monsoon (peak on July-August), with high indicated upwelling in around of southern pari of bay-mouth of Tomini Bay. The upwelling process in this area was governed by activity of northern lowei water mass in deep of $150 \mathrm{~m}$. The sea surface temperature decreased about $27.5-29.0^{\circ} \mathrm{C}$ during upwelling occurrence and the increase of chlorophyll-a concentration $\left(0.8-1.25 \mathrm{mg} \mathrm{m}^{-3}\right)$ was found. In situ measurement of sea surface temperature. Shows the low temperature of about 26.2 to $27.0^{\circ} \mathrm{C}$ and high salinity $(340$ $35.5 \%$ o) indicating upwelling phenomenon. Generally, plankton is concentrated in the mouthof bay, especially in southern of the bay (upwelling location) with abundance about $80.010-1.082 .520 \mathrm{cells} \mathrm{m}^{-3}$.

KEYWORDS: $\quad$ upwelling, sea surface temperature images, chlorophyll-a images, Tomini Bay

\section{PENDAHULUAN}

Teluk Tomini yang dikategorikan sebagai perairan laut dalam bersifat semi tertutup memiliki karakteristik oseanografi yang unik dan menarik untuk dikaji Memperhatikan letak dan posisi geografisnya banyak faktor yang akan mempengaruhi kondisi oseanografi Teluk Tomini. Variabilitas gerak massa air yang membawa konsekuensi pada pola sebaran suhu permukaan laut, tingkat produktivitas primer dan beberapa fenomena oseanografi penting lainnya seperti upwelling diduga juga terjadi di perairan ini terutama berkaitan dengan perubahan musim.

Secara umum, indikator yang menunjukkan terjadinya upwelling di suatu perairan selain mempengaruhi suhu dan salinitas juga mempengaruhi kandungan zat hara yang menandakan peningkatan kesuburan perairan (Arinardi, 1987). Penelitian Burhanuddin, et al. (2004) menyebutkan bahwa di perairan Teluk Tomini ditemukan indikasi adanya daerah upwelling yang ditandai dengan perubahan suhu yang terjadi di sekitar Teluk Tomini, Kepulauan Togean dan selatan Gorontalo yang intensitasnya semakin menguat; indikasi upwelling juga diduga terjadi di sepanjang Pantai Manado dan Bitung. Hasil simulasi model hidrodinamika 3 dimensi Ningsih, et al. (2003) memperlihatkan sebaran perubahan suhu permukaan laut di perairan Teluk Tomini pada bulan Agustus (musim timur) berkisar lebih dari 1 sampai dengan $3^{\circ} \mathrm{C}$. Dikatakan bahwa perubahan suhu permukaan laut yang besar di perairan Teluk Tomini tersebut merupakan indikasi terjadinya fenomena upwelling.

Peneliti pada Balai Riset Perikanan Laut, Jakarta 
Pengamatan terhadap suhu permukaan laut, sebaran klorofil-a sebagai indikator tingkat produktivitas primer suatu perairan selain dapat dilakukan secara langsung melalui pengukuran in situ juga dapat dilakukan secara tidak langsung melalui pengamatan menggunakan citra satelit. Teknologi satelit ini unggul dalam memetakan kondisi biofisik perairan secara berkala (Hendiarti, 2003). Kajian pemanfaatan data penginderaan jauh satelit untuk pengamatan suhu permukaan laut dan pola arus laut antara lain dilakukan oleh Hasyim, et al. (1996) untuk perairan Selat Sunda, Hendiarti et al. (1995) untuk perairan selatan Jawa dan Bali. Identifikasi awal untuk mengetahui daerah upwelling berdasarkan pada data penginderaan jauh di Indonesia dilaporkan terjadi di selatan Jawa dan Bali (Hendiarti et al., 1995) dan di Selat Makassar, Laut Sulawesi, dan Laut Banda (Utaminingsih, 1995), yaitu berdasarkan pada data sebaran suhu permukaan laut dari sensor thermal (thermal infra red) satelit National Oceanic and Atmospheric Administration-Advanced Very High Resolution Radiometer yang menunjukkan suhu rendah dibandingkan suhu perairan sekitarnya.

Selain menggunakan sensor thermal, pengamatan dengan sensor visible satelit inderaja warna air laut (ocean color) juga dapat memberikan informasi kondisi perairan khususnya kesuburan perairan yang digambarkan dengan konsentrasi klorofil-a. Inderaja ocean color mengukur radiasi spektrum sinar tampak yang dipantulkan dari bawah permukaan air (Hovis et al., 1980). Radiasi pantulan ini mengandung informasi sifat optik atau biooptik air laut yang diakibatkan oleh adanya bahan tersuspensi dan terlarut dalam air laut (Gordon \& Morel, 1983). Di perairan lepas pantai, komponen utama yang mempengaruhi sifat optik atau biooptik air laut adalah pigmen fitoplankton khususnya klorofil-a (Susilo, 1997). Fitoplankton menyerap energi cahaya pada panjang gelombang pendek sehingga terlihat adanya penurunan besarnya energi yang dipantulkan pada panjang gelombang tersebut.

Dalam tulisan ini dibahas indikasi dugaan terjadinya upwelling di perairan Teluk Tomini berdasarkan pada analisis komparatif citra suhu permukaan laut dan citra klorofil-a hasil pantauan 2 satelit berbeda. Analisis terhadap indikasi dugaan upwelling difokuskan pada periode musim timur yakni berdasarkan pada perubahan bulanan sebaran suhu permukaan laut dan klorofil-a dari 2 jenis citra satelit berbeda. Data oseanografi hasil pengukuran in situ (suhu, salinitas, dan data plankton) digunakan sebagai pembanding sekaligus bersifat menegaskan fenomena yang terlihat.

\section{BAHAN DAN METODE}

Untuk memudahkan pengamatan terhadap potensi munculnya indikator upwelling, maka lokasi pengamatan dalam penelitian ini meliputi seluruh perairan Teluk Tomini mulai bagian barat (ujung teluk) sampai dengan perairan di sekitar mulut teluk di bagian timur, serta perairan Laut Maluku dan Teluk Tolo yang berhubungan langsung dengan massa air Teluk Tomini. Rentang waktu pengamatan citra satelit meliputi tahun pengamatan 2002 sampai dengan 2004.

Untuk mengetahui pola sebaran suhu permukaan laut data yang digunakan adalah citra suhu permukaan laut hasil analisis digital dan visual dari sensor thermal satelit National Oceanic and Atmospheric Administration-Advanced Very High Resolution Radiometer. Untuk mengetahui pola sebaran dan konsentrasi klorofil-a yang menggambarkan kesuburan perairan (produktivitas primer) menggunakan data dari sensor visible Satelit Aqua Moderate resolution Imaging Spectroradiometer. Data oseanografi hasil pengukuran lapangan yang digunakan sebagai analisis pembanding adalah data hasil pengukuran in situ suhu, salinitas, dan kelimpahan plankton (fitoplankton) mewakili 2 musim yakni musim timur (2003) dan musim barat (2004). Pengukuran data oseanografi in situ (posisi pengukuran lihat: Suwarso et al., 2005; Dalam terbitan ini) dilakukan menggunakan Current Meter Valeport plus CTD Seri 108/308. Pengambilan contoh fitoplankton dan zooplankton dilakukan dengan menggunakan plankton net yang masing-masing berdiameter $25 \mathrm{~cm}$ (mata jaring/mesh size $60 \mu$ ) dan diameter $45 \mathrm{~cm}$ (mesh size $210 \mu$ ).

Citra suhu permukaan laut selain diolah dari data dengan resolusi $1 \mathrm{~km}$ yang diperoleh dari Lembaga Penerbangan dan Antariksa Nasional (citra tersebut sebagai pembanding tidak ditampilkan dalam tulisan ini), sebagian besar menggunakan data Advanced Very High Resolution Radiometer dengan resolusi 4 $\mathrm{km}$ yang diolah dari source data National Oceanic and Atmospheric Administration (NASA) kemudian dianalisis untuk melengkapi data bulanan yang tidak ter-cover. Data bersifat time series (bulanan) periode 2002 sampai dengan 2004 dalam format citra komposit (gabungan per bulan). Teknik pengolahan data sensor thermal Advanced Very High Resolution Radiometer menjadi citra suhu permukaan laut dilakukan dengan analisis split windows melalui pemrosesan citra kanal 3, 4, dan 5 dengan menggunakan software image processing $E$. $R$ Mapper 6.1. Metode penghitungan menggunakan formula McMillin \& Crosby (1984) sebagai berikut:

Split window; SPL $=\mathrm{T} 4+2.702(\mathrm{~T} 4-\mathrm{T} 5)-0,582-273,0$

Triple window; SPL=1.0239 T4+(0,9936(T3-T5)-278,46)

di mana:

T3 = brightness temperature channel 3

$\mathrm{T} 4$ = brightness temperature channel 4

T5 = brightness temperature channel 5

Citra klorofil-a merupakan data Moderate resolution Imaging Spectroradiometer periode Juni 
2003 sampai dengan Agustus 2004 dalam bentuk citra komposit (bulanan) yang diolah dari data website NASA (http://modis-ocean.gsfc.nasa.gov/). Data tersebut merupakan data level 2 (12) yang telah terkoreksi geometrik. Data Moderate resolution Imaging Spectroradiometer ini (dalam format Global Area Coverage dengan resolusi $4-9 \mathrm{~km}$ ) kemudian dicrooping sesuai dengan batas geografis daerah pengamatan $\left(2^{\circ} 00^{\prime} 00^{\prime \prime} \mathrm{LU}\right.$ sampai dengan $2^{\circ} 00^{\prime} 00^{\prime \prime} \mathrm{LS}$ dan $119^{\circ} 00^{\prime} 00^{\prime \prime}$ BT sampai dengan $126^{\circ} 00^{\prime} 00^{\prime \prime}$ BT). Untuk memudahkan pengamatan, nilai digital klorofil-a pada citra diolah tersendiri menggunakan Software Surfer 8.0 kemudian di-overlay pada citra yang kemudian dilengkapi dengan format kartografi standar untuk memudahkan dalam melakukan analisis visual.

\section{HASIL DAN BAHASAN}

\section{Pola Sebaran Suhu Permukaan Laut}

Nilai suhu permukaan laut perairan Teluk Tomini hasil pantauan sensor satelit National Oceanic and Atmospheric Administration-Advanced Very High Resolution Radiometer selama pengamatan (bulan Januari 2002 sampai dengan Mei 2003) berkisar antara 27,5 sampai dengan $31,5^{\circ} \mathrm{C}$ (Tabel 1) sementara pola sebaran suhu permukaan laut per bulan ditampilkan pada citra komposit bulanan (Lampiran 1). Dari analisis digital dan visual terhadap citra satelit terlihat bahwa sepanjang tahun suhu permukaan laut Teluk Tomini selalu lebih hangat dibanding suhu permukaan laut perairan lain di sekitarnya (Laut Maluku, Laut Seram, dan Laut Sulawesi).
Dari Tabel 1 terlihat bahwa suhu permukaan laut berfluktuasi secara bulanan dan juga bervariasi menurut region (barat, tengah, dan timur); suhu permukaan laut di bagian barat teluk selalu lebih panas dibanding suhu permukaan laut di bagian tengah dan timur teluk. Kondisi ini diduga karena perairan di bagian dalam teluk lebih sedikit mendapat pengaruh dari massa air dari luar teluk (Laut Maluku). Dari analisis digital terhadap nilai suhu permukaan laut pada citra satelit terlihat bahwa pada bulan April sampai dengan Juni dan Oktober sampai dengan Desember suhu lebih tinggi, penurunan suhu permukaan terjadi pada bulan Juli dan berlangsung selama musim timur, suhu permukaan laut paling rendah $\left(27,5^{\circ} \mathrm{C}\right)$ terjadi pada bulan September di perairan sebelah timur teluk (Laut Maluku), $28,0^{\circ} \mathrm{C}$ di bagian mulut teluk dan $29,0^{\circ} \mathrm{C}$ di bagian barat teluk. suhu permukaan laut tertinggi ditemukan selama bulan November sampai dengan Desember (musim barat), masing-masing dengan nilai $30,0^{\circ} \mathrm{C}$ di bagian timur teluk, $30,5^{\circ} \mathrm{C}$ di bagian mulut teluk, dan $31,5^{\circ} \mathrm{C}$ di bagian barat teluk.

Dari pola citra suhu permukaan laut secara bulanan terlihat bahwa massa air permukaan sekitar mulut teluk merupakan perluasan massa air Laut Maluku, Teluk Tolo, dan sebelah selatan Halmahera. Pada musim timur di perairan sekitar mulut teluk dan timur teluk (Laut Maluku) memiliki nilai sebaran suhu permukaan laut yang lebih rendah. Massa air dengan suhu permukaan laut rendah pada musim timur digambarkan pada citra berwarna biru hijau. Sementara itu, pada musim barat di Laut Maluku mengalir massa air permukaan bersuhu tinggi. Dari polanya terlihat massa air ini berasal dari arah selatan

Tabel 1. Nilai sebaran bulanan suhu permukaan laut perairan Teluk Tomini berdasarkan pada citra satelit

Table 1. Monthly sea surface temperature in Tomini Bay based on satelite mages

\begin{tabular}{ccccc}
\hline \multicolumn{2}{c}{ Periode pengamatan citra } & \multicolumn{3}{c}{ Sebaran suhu permukaan laut $\left({ }^{\circ} \mathbf{C}\right)$} \\
\hline Tahun & Bulan & Dalam teluk & Mulut teluk & Timur/Luar teluk \\
\hline 2002 & Januari & 29 & 30 & 29 \\
& Pebruari & 30 & 30 & 29 \\
& Maret & 29 & 30 & 29 \\
& April & 31 & 30,5 & 30 \\
Mei & 31 & 30 & 29 \\
Juni & 31 & 29,5 & 28,5 \\
Juli & 30 & 29 & 28 \\
& Agustus & 29 & 28,5 & 27,5 \\
& September & 29 & 28 & 29,5 \\
& Oktober & 30,5 & 30 & 30 \\
& Nopember & 31,5 & 30,5 & 30 \\
& Desember & 31,5 & 30 & 29 \\
& Januari & 29,5 & 30 & 28,5 \\
& Pebruari & 28 & 29,5 & 28,5 \\
& Maret & 29 & 30 & 30 \\
& April & 31 & 30,5 & 29 \\
\hline
\end{tabular}


dan tenggara (kemungkinan dari Laut Banda). Massa air dengan suhu permukaan laut tinggi pada musim barat pada citra dipresentasikan sebagai massa air berwarna kuning merah. Pola-pola citra suhu permukaan laut menunjukkan massa air permukaan bersuhu tinggi pada musim barat tersebut masuk ke Teluk Tomini di daerah mulut teluk bagian selatan melalui Teluk Tolo.

Menurut Wyrtki (1961) selama musim tenggara atau timur massa air permukaan yang keluar dari Samudra Pasifik di sebelah utara Irian mengalir melalui Halmahera dan Laut Seram, kemudian di sebelah utara Pulau Buru arus bercabang 2, cabang pertama mengalir melalui Laut Banda dan langsung ke arah barat daya menuju Laut Flores, sedangkan cabang lainnya kembali ke Samudra Pasifik melalui Laut Maluku (sebelah barat Halmahera) dan bergabung dengan cabang arus Mindanao yang mengalir di Laut Sulawesi dari arah barat dan bersama-sama keduanya merupakan akar dari counter current. Burhanuddin et al. (2004) mempertegas pola-pola massa air yang memasuki Laut Maluku seperti diuraikan di atas.

Dari hasil pengukuran in situ pada musim timur tahun 2003 menunjukkan kesamaan pola seperti yang ditunjukkan data citra, yaitu bahwa suhu perairan di sekitar mulut teluk lebih dingin dan ke arah barat semakin hangat; di sisi lain, dalam arah timur ke barat ini salinitas cenderung semakin rendah (Suwarso et al., 2005; Dalam terbitan ini). Dari hasil pengukuran in situ pada 36 stasiun tersebut nilai suhu permukaan laut berkisar antara 27,5 sampai dengan $30,5^{\circ} \mathrm{C}$ yang berarti bahwa hasil pengukuran in situ menunjukkan nilai suhu permukaan laut yang sama dengan hasil pengukuran satelit.
Kecenderungan yang sama juga terlihat baik berdasarkan pada data citra maupun pengukuran in situ, yaitu bahwa suhu permukaan laut di perairan bagian utara pada musim timur lebih rendah dibandingkan dengan bagian selatan. Hal ini, diduga akibat pengaruh massa air dari Laut Maluku yang bersuhu rendah mengalir dan menyusur pantai sebelah utara, selanjutnya aliran massa air permukaan tersebut mendesak massa air ke arah barat dan selatan teluk sepanjang pantai Sulawesi Tengah dan Teluk Poso. Dari citra suhu permukaan laut juga mengindikasikan bahwa terdapat lebih sedikit pertukaran massa air permukaan di sebelah barat dan selatan teluk (Teluk Poso) dibandingkan di perairan sebelah timur dan utara teluk. Pola pergerakkan arus permukaan demikian juga dikemukakan oleh Burhanuddin et al. (2004).

\section{Pola Sebaran Klorofil-a}

Dari hasil analisis digital-visual terhadap citra komposit klorofil-a secara bulanan hasil pantauan sensor Moderate resolution Imaging Spectroradiometer diketahui nilai sebaran klorofil-a di Teluk Tomini, Laut Maluku bervariasi menurut musim dan lokasi, secara umum nilai-nilai maksimum berkisar antara 0,13 sampai dengan $1,25 \mathrm{mg} \mathrm{m}^{-3}$. Nilai kandungan klorofil-a hasil pantauan sensor Moderate resolution Imaging Spectroradiometer menurut musim dan lokasi selengkapnya dipresentasikan pada Tabel 2.

Dengan memisahkan daerah pengamatan menjadi 3 zona, yaitu perairan di dalam teluk, sekitar mulut teluk, dan daerah di luar teluk sebelah timur (Laut Maluku), terlihat bahwa perairan sekitar mulut teluk memiliki kandungan klorofil-a yang lebih tinggi (antara

Tabel 2. Nilai kandungan klorofil-a (nilai sebaran tertinggi) di perairan Teluk Tomini pada bulan Juni 2003 sampai Agustus 2004 dari hasil pengamatan citra Moderate resolution Imaging Spectroradiometer

Table 2. Chlorophyll-a content taken from Moderate resolution Imaging Spectroradiometer images in Tomini Bay, June 2003 to August 2004

\begin{tabular}{|c|c|c|c|c|}
\hline \multicolumn{2}{|c|}{ Periode pengamatan } & \multicolumn{3}{|c|}{ Kandungan klorofil-a (mg m$\left.~^{-3}\right)$} \\
\hline Tahun & Bulan & Dalam teluk & Mulut & Timur/Luar teluk \\
\hline \multirow{7}{*}{2003} & Juni & 0,3 & 0,41 & 0,56 \\
\hline & Juli & 0,53 & 0,83 & 0,65 \\
\hline & Agustus & 0,32 & 0,47 & 0,63 \\
\hline & September & 0,2 & 0,41 & 0,51 \\
\hline & Oktober & 0,2 & 0,4 & 0,5 \\
\hline & Nopember & 0,13 & 0,56 & 0,36 \\
\hline & Desember & 0,15 & 0,32 & 0,38 \\
\hline \multirow{8}{*}{2004} & Januari & 0,16 & 0,44 & 0,33 \\
\hline & Pebruari & 0,15 & 0,41 & 0,28 \\
\hline & Maret & 0,18 & 0,33 & 0,41 \\
\hline & April & 0,13 & 0,36 & 0,29 \\
\hline & Mei & 0,15 & 0,56 & 0,38 \\
\hline & Juni & 0,2 & 0,47 & 0,53 \\
\hline & Juli & 0,25 & 0,56 & 0,6 \\
\hline & Agustus & 0,26 & 1,25 & 0,83 \\
\hline
\end{tabular}


0,32 sampai dengan 1,25 $\mathrm{mg} \mathrm{m}^{-3}$ ) dibandingkan dengan perairan di dalam teluk (antara 0,13 sampai dengan $0,53 \mathrm{mg} \mathrm{m}^{-3}$ ) dan perairan di luar teluk (Laut Maluku) yang nilainya berkisar antara 0,28 sampai dengan $0,83 \mathrm{mg} \mathrm{m}^{-3}$. Kandungan klorofil-a mencapai puncaknya pada sekitar musim timur (bulan Juli sampai dengan Agustus), sedang terendah ditemukan pada musim barat (bulan Nopember sampai dengan Januari). Secara umum, terlihat baik di mulut teluk maupun di luar teluk (Laut Maluku) pada musim timur terjadi lonjakan kosentrasi klorofil-a yang signifikan, nilai maksimum mencapai $0,83 \mathrm{mg} \mathrm{m}^{-3}$ (2003) dan $1,25 \mathrm{mg} \mathrm{m}^{-3}$ (2004) di bagian mulut teluk; sedang di bagian luar teluk (Laut Maluku) nilainya $0,65 \mathrm{mg} \mathrm{m}^{-3}$ (2003) dan $0,85 \mathrm{mg} \mathrm{m}^{-3}$. Di bagian dalam teluk nilai klorofil-a tertinggi hanya ditemukan pada bulan Juli $2003\left(0,53 \mathrm{mg} \mathrm{m}^{-3}\right)$ sementara pada musim timur (bulan Juli) 2004 tidak ditemukan lonjakan kandungan klorofil-a.

Dari hal tersebut dapat diduga bahwa perairan sekitar mulut teluk memiliki kesuburan paling tinggi dibandingkan perairan di dalam teluk dan di luar teluk (Laut Maluku), khususnya pada musim timur. Indikator kesuburan selain dinyatakan dengan konsentrasi klorofil-a dan nutrien, juga dapat dinyatakan dengan kelimpahan plankton. Hasil pengambilan contoh plankton pada bulan Juli sampai dengan Agustus
2004 (musim timur) di seluruh perairan Teluk Tomini (36 stasiun) menegaskan hal tersebut. Dari kelimpahan fitoplankton yang berkisar antara 80.0101.082 .520 sel $\mathrm{m}^{-3}$ (rata-rata $263.963 \mathrm{sel} \mathrm{m}^{-3}$ ), kelimpahan yang lebih tinggi terkonsentrasi di perairan sekitar mulut teluk, yaitu berkisar antara

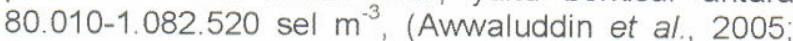
Dalam terbitan ini); pusat-pusat pengelompokkan (patchiness) terdapat di mulut teluk sebelah selatan (sekitar Bualemo, Banggai; stasiun 35 sampai dengan 37), bagian tengah perairan dan perairan sebelah selatan Minahasa (stasiun 2 sampai dengan 6). Diatomae merupakan kelompok fitoplankton yang paling dominan (93\%) ditemukan sekitar 35 genus (Awwaluddin et al., 2005; Dalam terbitan ini).

\section{Dugaan Potensi Upwelling dan Faktor Fisik Kemungkinan Pemicunya}

Fenomena upwelling dicirikan oleh penurunan suhu yang tajam disertai lonjakan kandungan nutrien di sekitar region upwelling (Mann \& Lazier, 1991; Arinardi et al., 1997; Wyrtki, 1961). Kondisi suhu rendah dapat disertai dengan salinitas lebih tinggi yang merupakan kualifikasi dari massa air yang terumbal ke permukaan dengan membawa serta banyak nutrien.

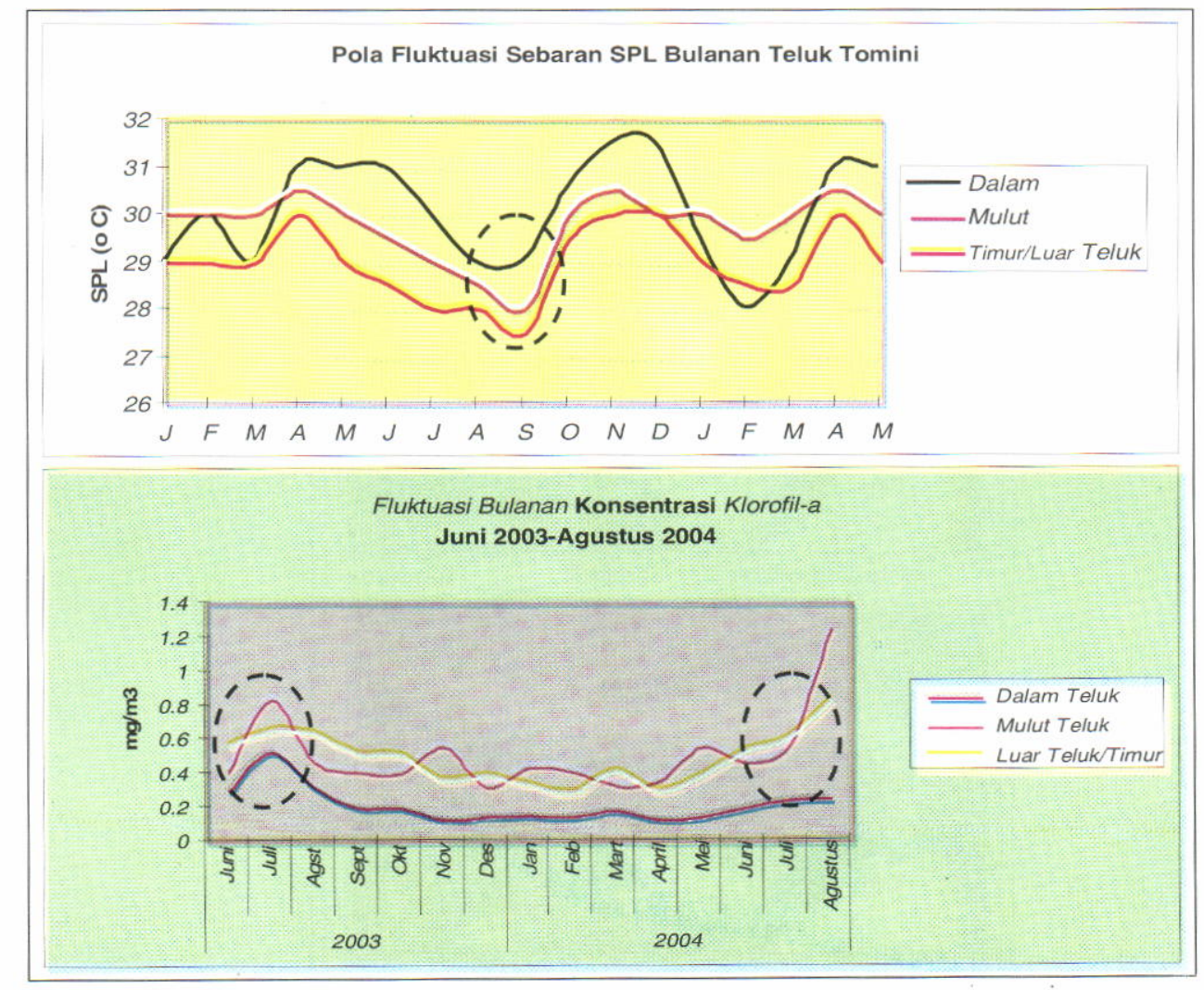

Gambar 1.

Grafik fluktuasi suhu permukaan (atas) dan konsentrasi klorofil-a (bawah). Lingkaran putus menunjukkan indikator umum terjadinya upwelling.

Figure 1. Sea surface temperature fluctuation (above) and chlorophyll-a distribution (below). The black circle indicate the upwelling. 
Dari data citra satelit terlihat terjadi penurunan suhu permukaan yang diikuti dengan peningkatan konsentrasi klorofil-a pada bulan Juli sampai dengan Agustus atau musim timur (Gambar 1). Parameter suhu (penurunan yang tajam) merupakan indikator umum yang dipakai mencirikan fenomena tersebut, sedangkan klorofil-a merupakan properti dari fitoplankton yang melakukan fotosintesis dan merespon lonjakan kandungan nutrient di lahan sekitar upwelling. Berdasarkan pada hal tersebut diduga pada musim timur terjadi penaikan massa air bawah yang disertai nutrien ke permukaan (upwelling); intensitasnya terutama terjadi di daerah mulut teluk bagian selatan. Konsentrasi nutrien atau unsur hara yang tinggi dicirikan oleh Ionjakan kandungan klorofil-a sebagai indikator kesuburan yang pada citra satelit Moderate resolution Imaging Spectroradiometer dicirikan dengan warna kuningmerah yang menandakan konsentrasi klorofil-a tinggi (Gambar 2). Pola distribusi spatial plankton pada musim timur yang terkonsentrasi di sekitar daerah dugaan upwelling di mulut teluk (Awwalludin et al., 2005; Dalam terbitan ini); seperti juga yang pernah dikemukan oleh Wiadnyana (1998) menegaskan hal tersebut; baik fitoplankton, zooplankton, dan icthyoplankton yang merupakan komunitas dasar dalam sistim perairan terkonsentrasi di sekitar mulut teluk.

Pada musim timur, suhu permukaan terendah ditemukan sebesar $27,5^{\circ} \mathrm{C}$, yaitu di luar teluk (Laut Maluku), sedang di sekitar mulut teluk $28,0^{\circ} \mathrm{C}$. Dari pengukuran in situ pada bulan Juli sampai dengan Agustus 2003 suhu permukaan di lahan sekitar mulut teluk lebih rendah dan berkisar antara 26,2 sampai dengan $27,0^{\circ} \mathrm{C}$, salinitas permukaan cenderung lebih tinggi dan berkisar antara 34,0 sampai dengan $34,5 \%$ o (Suwarso et al., 2005; Dalam terbitan ini). Gambar 3 menunjukkan sebaran mendatar salinitas di Teluk Tomini pada bulan Juli sampai dengan Agustus 2003 (musim timur). Pada musim yang sama, citra satelit Moderate resolution Imaging Spectroradiometer (Gambar 2) memperlihatkan terjadinya peningkatan kandungan klorofil-a cukup tinggi, yaitu sekitar 0,6 sampai dengan $0,8 \mathrm{mg} \mathrm{m}^{-3}$ pada bulan Juli di luar teluk (Laut Maluku) dan sekitar 0,8 sampai dengan $1,25 \mathrm{mg} \mathrm{m}^{-3}$ di mulut teluk. Hasil penelitian Hendiarti (2003) menggunakan citra satelit di zona upwelling perairan selatan Jawa menunjukkan pada musim upwelling (musim timur) suhu permukaan laut menjadi lebih rendah $<28^{\circ} \mathrm{C}$ (27 sampai dengan $28^{\circ} \mathrm{C}$ ) yang diikuti oleh naiknya kandungan klorofil-a 0,8 sampai dengan $2,0 \mathrm{mg} \mathrm{m}^{-3}$.

Herlisman (1996) mengkaji indikasi upwelling di selatan Jawa Tengah sebelah timur, hasil menunjukkan pada bulan Agustus terdapat massa air dingin di permukaan sekitar pantai, suhunya berkisar antara 28,0 sampai dengan $28,9^{\circ} \mathrm{C}$ dengan selisih suhu tertinggi antara musim barat dengan musim timur sebesar $4^{\circ} \mathrm{C}$ (hasil citra satelit) atau antara 26,1 sampai dengan $27,6^{\circ} \mathrm{C}$ dari hasil pengukuran in situ; salinitas rata-rata di permukaan $34,02 \%$. Menurut Nontji (1974) rata-rata konsentrasi klorofil-a

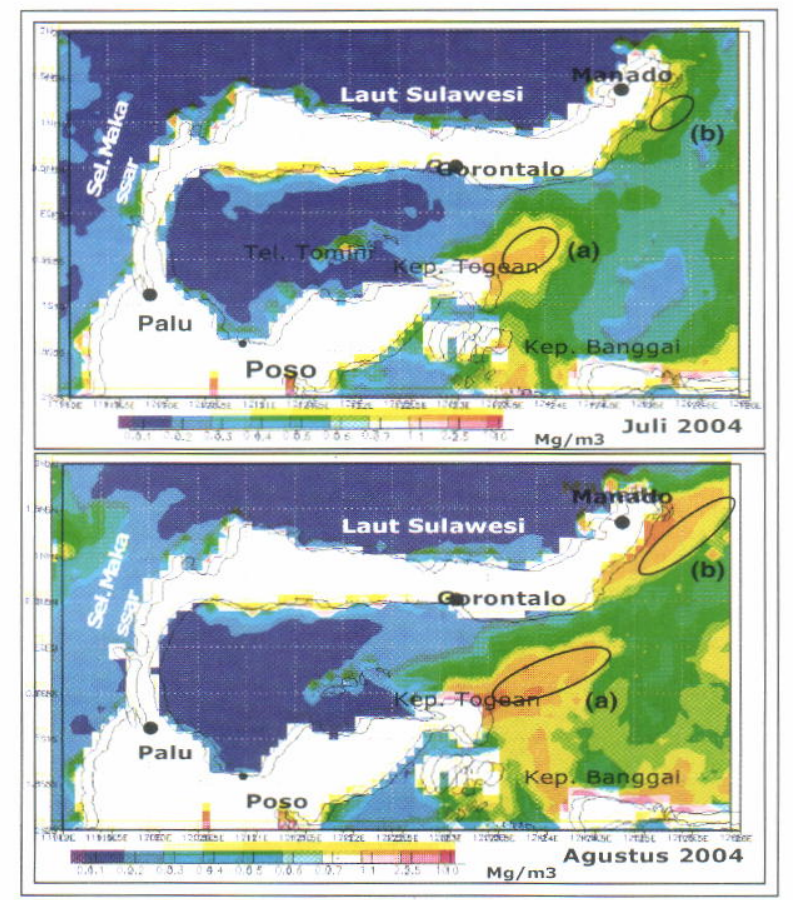

Gambar 2. Indikator dugaan upwelling dari citra Moderate resolution Imaging Spectroradiometer bulan Juli sampai dengan Agustus 2004

Figure 2. The upwelling indicator based on the Moderate resolution Imaging Spectroradiometer images in July-August 2004. 


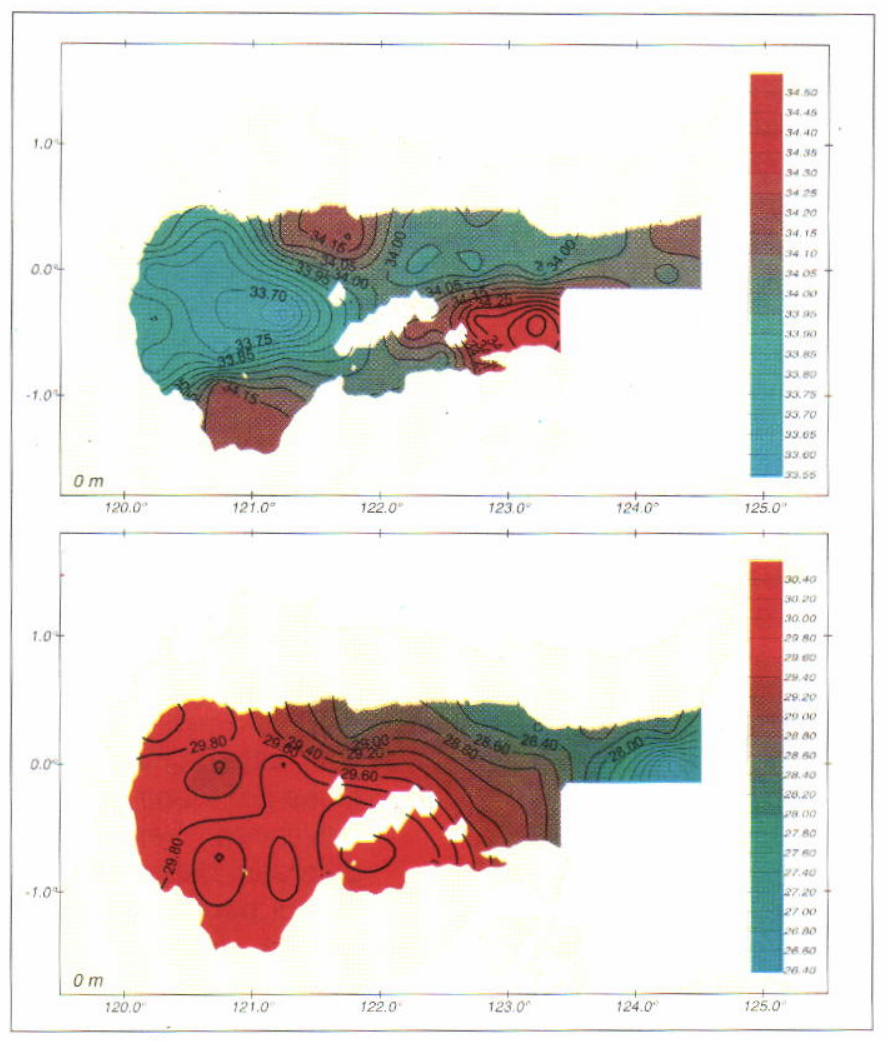

Gambar 3. Sebaran mendatar salinitas (atas) dan suhu permukaan laut (bawah) hasil pengukuran in situ pada musim timur tahun 2003.

Figure 3. Horizontal distribution of salinity (above) and sea surface temperature (below) resulted from in situ measerement on east season 2003.

fitoplankton di perairan Indonesia $0,19 \mathrm{mg} \mathrm{m}^{-3}$; pada musim timur (periode upwelling di Indonesia timur) nilainya lebih tinggi $0,24 \mathrm{mg} \mathrm{m}^{-3}$, dan bahkan dapat mencapai 15 kali lebih besar dari keadaan normal atau sekitar $4,0 \mathrm{mg} \mathrm{m}^{-3}$ di Laut Banda (Wiadnyana, 1999), sedangkan pada musim barat $0,16 \mathrm{mg} \mathrm{m}^{-3}$. Syamsudin (2004) menambahkan bahwa pada saat terjadi upwelling, kenaikan massa air dari kedalaman yang lebih dingin pada umumnya memiliki suhu antara 25 sampai dengan $27^{\circ} \mathrm{C}$, sementara rata-rata suhu permukaan di perairan Indonesia (kondisi normal) berkisar 28 sampai dengan $29^{\circ} \mathrm{C}$.

Jika dibandingkan dengan data hasil penelitian Badan Riset Kelautan dan Perikanan (2003) terlihat adanya kesamaan sebaran nilai suhu permukaan laut yang secara umum berkisar 27 sampai dengan $30^{\circ} \mathrm{C}$. Sedangkan hasil simulasi model hidrodinamika 3 dimensi oleh Ningsih, et al. (2003) memperlihatkan sebaran perubahan suhu permukaan laut di perairan Teluk Tomini pada bulan Agustus (musim timur) berkisar lebih dari 1 sampai dengan $3^{\circ} \mathrm{C}$. Menurut Ningsih, et al. (2003) perubahan suhu permukaan laut yang besar tersebut mengindikasikan terjadinya fenomena upwelling.

Meskipun lokasi spesifik dari penurunan suhu (citra suhu permukaan laut) tidak dapat terlihat secara jelas, namun indikasi upwelling dapat diidentifikasi dengan mudah pada citra klorofil-a (Gambar 2) yang terlihat dari nilai klorofil-a yang tinggi. Pada bulan Juni di sekitar mulut teluk sebelah selatan (zona a) atau daerah pantai atau lepas pantai di ujung timur Sulawesi Tengah (Kabupaten Banggai) mulai terlihat peningkatan kandungan klorofil-a; pada bulan Juli intensitasnya semakin menguat dengan cakupan semakin luas. Pada foto citra kandungan klorofil-a yang tinggi ditandai dengan warna kuning merah atau cokelat. Selain itu, indikasi terjadinya upwelling juga terlihat di (zona b) atau sepanjang pantai timur Nuangan (Minahasa Selatan), pantai timur Bitung sampai dengan sekitar Serai di Manado. Pada bulan Agustus kandungan klorofil-a di daerah mulut bagian selatan (zona a) mencapai $1,25 \mathrm{mg} \mathrm{m}^{-3}$.

Pada umumnya upwelling dapat terjadi akibat hembusan angin secara terus-menerus dengan kecepatan cukup besar dan dalam waktu yang cukup lama seperti yang terjadi di Laut Banda (Wiadnyana, 1998). Upwelling tipe inilah yang dimungkinkan terjadi di perairan mulut sebelah utara (sekitar Pantai Nuangan). Pada musim timur angin berhembus dari selatan sampai dengan tenggara menuju ke utara, akibat gaya Coriolis (gaya yang timbul akibat perputaran bumi pada porosnya) massa air permukaan (lapisan Ekman) di Pantai Nuangan akan 
bergerak menjauhi pantai dengan arah tegak lurus ke arah laut lepas (Ekman transport). Peristiwa tersebut menyebabkan terbentuknya ruang kosong di daerah pantai Nuangan yang kemudian akan diisi oleh massa air di bawahnya bergerak vertikal ke permukaan dengan membawa serta nutrien dari bawah. Arus laut dan topografi atau bathimetry dasar perairan turut menentukan proses terjadinya upwelling.

Namun, tipe coastal upwelling seperti tersebut di atas sangat kecil kemungkinannya (tidak mungkin) terjadi di daratan timur Sulawesi Tengah (Banggai), karena posisinya di sebelah selatan khatulistiwa transport Ekman akan menuju daratan. Hal yang mungkin diduga berupa transport massa air bawah membelok menuju permukaan akibat membentur tubir daratan Kabupaten Banggai yang mungkin curam. Pembelokan massa air bawah secara vertikal ke permukaan mengangkut juga nutrien. Pola arus permukaan diduga memberi pola penyebaran klorofila (plankton) di daerah tersebut.

Dengan melihat topografi dasar perairan, diduga kontur batimetri yang terdapat di daerah sekitar mulut teluk. Dari peta bathimetri terlihat bahwa bentuk topografi dasar perairan di mulut Teluk Tomini memiliki perbedaan kedalaman yang sangat variatif dengan kedalaman yang terdalam sekitar 3.000 sampai dengan $4.000 \mathrm{~m}$ berada di bagian timur teluk dan makin ke barat ke arah daratan Sulawesi perubahan kedalaman secara drastis menjadi ratusan meter sehingga memunculkan adanya daerah tubir di sekitar mulut teluk bagian selatan sampai dengan ke sekitar Pulau Togean.

Dari data pengukuran in situ indikasi upwelling dibuktikan dengan adanya kemiringan garis isoterm (sebaran melintang suhu) dan isohaline (sebaran melintang salinitas) yang menaik ke arah sekitar bagian selatan mulut teluk (transek 3) antara kedalaman sekitar 125 m permukaan (Suwarso et. al., 2005; Dalam terbitan ini). Lereng isoterm dan isohalin yang menaik tersebut diduga terjadi akibat adanya dorongan (gerakkan) massa air dari lapisan yang lebih dalam ke atas di mana massa air ini memiliki salinitas lebih tinggi suhu lebih rendah yang dalam penelitian ini dari data satelit juga diindikasikan dengan meningkatnya nilai sebaran klorofil-a yang menandakan terjadinya peningkatan produktivitas primer perairan. Massa air di lapisan dalam yang memicu terjadinya upwelling di bagian mulut Teluk Tomini diduga sesuai dengan temuan Wyrtki (1961) yang menyebutkan bahwa pada musim timur aliran massa air di perairan sebelah timur Sulawesi sangat dipengaruhi oleh arus massa air dalam (northern lower water, kedalaman $150 \mathrm{~m}$ ) yang dari Samudera Pasifik. Massa air inilah yang ketika sampai di Laut Maluku pada musim timur mendesak massa air di mulut Teluk Tomini. Burhanuddin et al. (2004) pada penelitian sebelumnya menyebutkan dugaan zona potensi upwelling di Teluk Tomini berdasarkan pad data citra satelit, yakni di perairan sekitar Kepulauan
Togean dan sepanjang pesisir selatan Puhuwato (Propinsi Gorontalo) yang intensitasnya tidak sekuat ke-2 lokasi tersebut di atas. Indikasi peningkatan kandungan klorofil-a yang tinggi pada musim timur juga terlihat di sebelah timur Kepulauan Banggai, Teluk Tolo (lihat Gambar 2).

Untuk menegaskan dugaan di atas perlu dilakukan pengkajian lebih lanjut secara komprehensif melalui pengambilan contoh dan pengukuran secara in situ terhadap berbagai faktor fisik perairan maupun biologi perairan (nitrat, silikat, dan fosfat) yang dalam penelitian ini tidak dilakukan. Pengkajian biologi perairan atau biologi bahari terkait potensi upwelling sangat penting bagi produktivitas perikanan di Teluk Tomini dan sekitarnya.

\section{KESIMPULAN DAN SARAN}

1. Dari citra suhu permukaan laut satelit National Oceanic and Atmospheric AdministrationAdvanced Very High Resolution Radiometer diketahui bahwa pada musim timur secara umum terjadi penurunan suhu permukaan laut di Teluk Tomini dengan kisaran 27,5 sampai dengan $29,0^{\circ} \mathrm{C}$. Sementara dari citra klorofil-a Moderate resolution Imaging Spectroradiometer di beberapa lokasi tertentu yakni di mulut teluk bagian selatan, perairan selatan sampai dengan tenggara Bitung, sekitar Pulau Togian dan pesisir barat Gorontalo terjadi peningkatan kosentrasi klorofil-a dengan kisaran tertinggi 0,8 sampai dengan $1,25 \mathrm{mg} \mathrm{m}^{-3}$ yang mengindikasikan adanya upwelling.

2. Hasil pengukuran in situ terhadap suhu dan salinitas pada musim timur memperkuat dugaan terjadinya upwelling pada daerah yang pada citra Moderate resolution Imaging Spectroradiometer terlihat mengalami peningkatan kandungan klorofil-a yang signifikan ditandai dengan suhu permukaan laut yang rendah 26,2 sampai dengan $27,0^{\circ} \mathrm{C}$ dan peningkatan salinitas lebih tinggi dari perairan sekitarnya yakni 34,0 sampai dengan $35,5 \%$.

3. Massa air dari Samudera Pasifik pada musim timur yang oleh Wyrtki (1961) disebut arus massa air dalam (northern lower water, kedalaman $150 \mathrm{~m}$ ) mendesak massa air di mulut Teluk Tomini yang diduga memicu terjadinya upwelling akibat berbenturan dengan daerah tubir di mulut teluk. Sementara itu, di daerah pesisir barat Gorontalo upwelling disebabkan oleh angin (coastal upwelling).

4. Disarankan periunya pengkajian lebih lanjut tentang variabilitas dari fenomena upwelling di Teluk Tomini terkait dengan dinamika plankton dan sumber daya ikan di daerah ini. 


\section{DAFTAR PUSTAKA}

Arinardi, O. H., A. B. Sutomo, \& S. A. Yusuf. 1997 Kisaran kelimpahan dan komposisi plankton predominan di perairan kawasan timur Indonesia. Pusat Penelitian dan Pengembangan Oseanologi. Lembaga IImu Pengetahuan Indonesia. Jakarta.

Awwaluddin, Suwarso, \& Rahmat S. 2005. Distribusi kelimpahan dan struktur komunitas plankton pada musim timur di perairan Teluk Tomini. Jurnal Penelitian Perikanan Indonesia Vol.11 No.6 Tahun 2005. Dalam terbitan ini. Jakarta.

Birowo, S. 1975. Upwelling atau kenaikan air. Pewarta Oseana, 2 (3): 1-7. LON-Lembaga IImu Pengetahuan Indonesia. Jakarta.

Badan Riset Kelautan dan Perikanan. 2002. Peta oseanografi wilayah perairan Indonesia, integrasi data riset kelautan dan perikanan. Badan Riset Kelautan dan Perikanan. Departemen Kelautan dan Perikanan. Jakarta.

Burhanuddin, Agus S., \& Tony W. (Eds.). 2004. Profil sumber daya kelautan Teluk Tomini. Badan Riset Kelautan dan Perikanan. Departemen Kelautan dan Perikanan. Jakarta.

Gordon, H. R. \& Morel, A. 1983. Remote Assessment of Ocean Color for Interpretation of Sattelite Visible Imagery: a review. In lecture notes on Coastal and Estuarine Studies, editied by M. Bowman (Berlin: Springer-Verlag). pp. 1-114.

Hendiarti, N. 1995. Pendugaan lokasi upwelling di perairan selatan Pulau Jawa-Bali berdasarkan pada tinjauan parameter fisika oseanografi dan konsentrasi klorofil-a. Makalah Prosiding Seminar Kelautan Nasional 1995. Panitia Pengembangan Riset dan Teknologi Kelautan serta Industri Maritim. Jakarta.

Hendiarti, N. Satelit pemantau fitoplankton. Artikel ilmiah Harian Kompas Kamis, 27 Nopember 2003. Jakarta.

Hasyim, B., Khairul A., \& Maryani H. 1996. Pemanfaatan data penginderaan jauh NOAAAVHRR untuk pengamatan pola arus laut dan daerah potensi penangkapan ikan. Prosiding Seminar Konvensi Nasional Pembangunan Benua Maritim Indonesia. Direktorat Teknologi Inventarisasi Sumber Daya Alam (TISDA)-BPPT dan Dewan HANKAMNAS. Jakarta

Suwarso \& Herlisman. 2005. Profil fisik massa air di Teluk Tomini pada Musim Timur. Jurnal Penelitian Perikanan Indonesia Vol.11 No.6 Tahun 2005. Dalam terbitan ini. Jakarta.
Ilahude, A. G. 1970. On the occurence of upwelling in Southern Makassar Strait. Marine Research in Indonesia. 10: 3-23.

1978. On the affecting the productivity of the Southern Makassar Strait. Marine Research in Indonesia. 21: 81-107.

McMillin, L. M. D. S. Crosby. 1984. Theory and validation of the multiple window sea surface temperature technique. Journalist Geophy. Resources. 89 (C): 3655-3661

Mann, K. H. \& J. R. N. Lazier. 1991. Dynamics of marine ecosystem. Biological-Physical Interactions in the Ocean. Blackwell Scientific Publication, Boston.

Nair, N. B. \& D. M. Thampy. 1980. A textbook of marine ecology. University of LCUE. India.

Ningsih, N. S., Berlianty D., Latief, H., \& Frida. 2003. Peningkatan informasi peta fishing ground melalui integrasi dan kalibrasi atau validasi model 3 dimensi hidrodinamika. Laporan Intrerim. PS Oseanografi. Institut Teknologi Bandung. Departemen Kelautan dan Perikanan.

Nontji, A. 1974. Kandungan klorofil pada fitoplankton di Laut Banda dan Seram. Oseanologi Indonesia (2): $1-16$

Pond, S. \& G. L. Pickard. 1983. Introductory dynamical oceanography. Pergamon Press. England.

Susilo, S. B. 1997. Penginderaan jauh warna air laut (ocean color remote sensing). Fakultas Perikanan Institut Pertanian Bogor. Bogor. (Tidak dipublikasikan)

Suwarso \& Herlisman. 2005. Profil fisik massa air di Teluk Tomini pada Musim Timur. Jurnal Penelitian Perikanan Indonesia Vol.11 No.6 Tahun 2005. Dalam terbitan ini. Jakarta.

Syamsudin, F. 2004. Mencari lokasi upwelling. Artikel ilmiah Harian Kompas Senin, 2 Pebruari 2004. Jakarta.

Sumich, J. L. 1992. An introduction to the biology of marine life. Wm. C. Brown Publishers. USA.

Syahailatua, A. 2004. Fenomena upwelling dan sumber daya ikan: lokasi penangkapan vs lokasi pemijahan. Artikel ilmiah KOMPAS Minggu, $20 \mathrm{Juli}$ 2003. Jakarta.

Utaminingsih. 1995. Pendugaan lokasi upwelling dengan menggunakan data penginderaan jauh. 
Makalah Prosiding Seminar Kelautan Nasional 1995. Panitia Pengembangan Riset dan Teknologi Kelautan serta Industri Maritim. Jakarta.

Wiadnyana, N. N. 1999. Variasi kelimpahan zooplankton dalam kaitannya dengan produktivitas perairan Laut Banda. Oseanologi dan Limnologi d Indonesia. 31: 57-68.

Wiadnyana, N. N. 1998. Distribusi dan variasi pigmen fitoplankton di Teluk Tomini, Sulawesi Utara. Prosiding Seminar Kelautan Lembaga IImu Pengetahuan Indonesia-Universitas Hasanuddin ke-1. 248-259.

Wyrtki, K. 1961. Physical oceanography of the southeast asian waters. The University of California, Scripps Institution of Oceanography. La Jolla. California. Naga Rep. 2:1-195. 
Lampiran 1. Citra suhu permukaan laut bulan Januari 2002 sampai dengan Mei 2003

Appendix 1. Sea surface temperature images on January 2002-May 2003

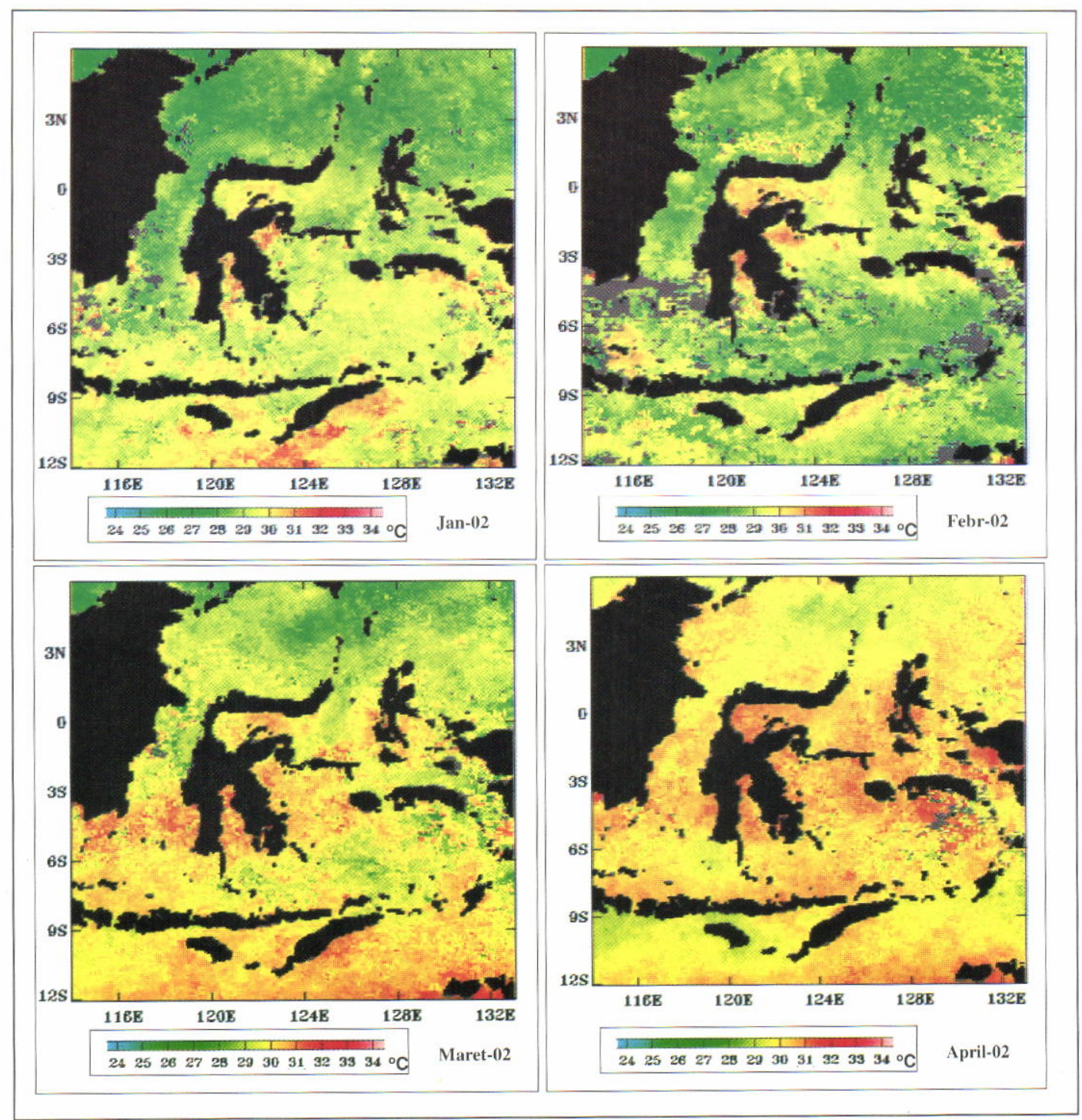




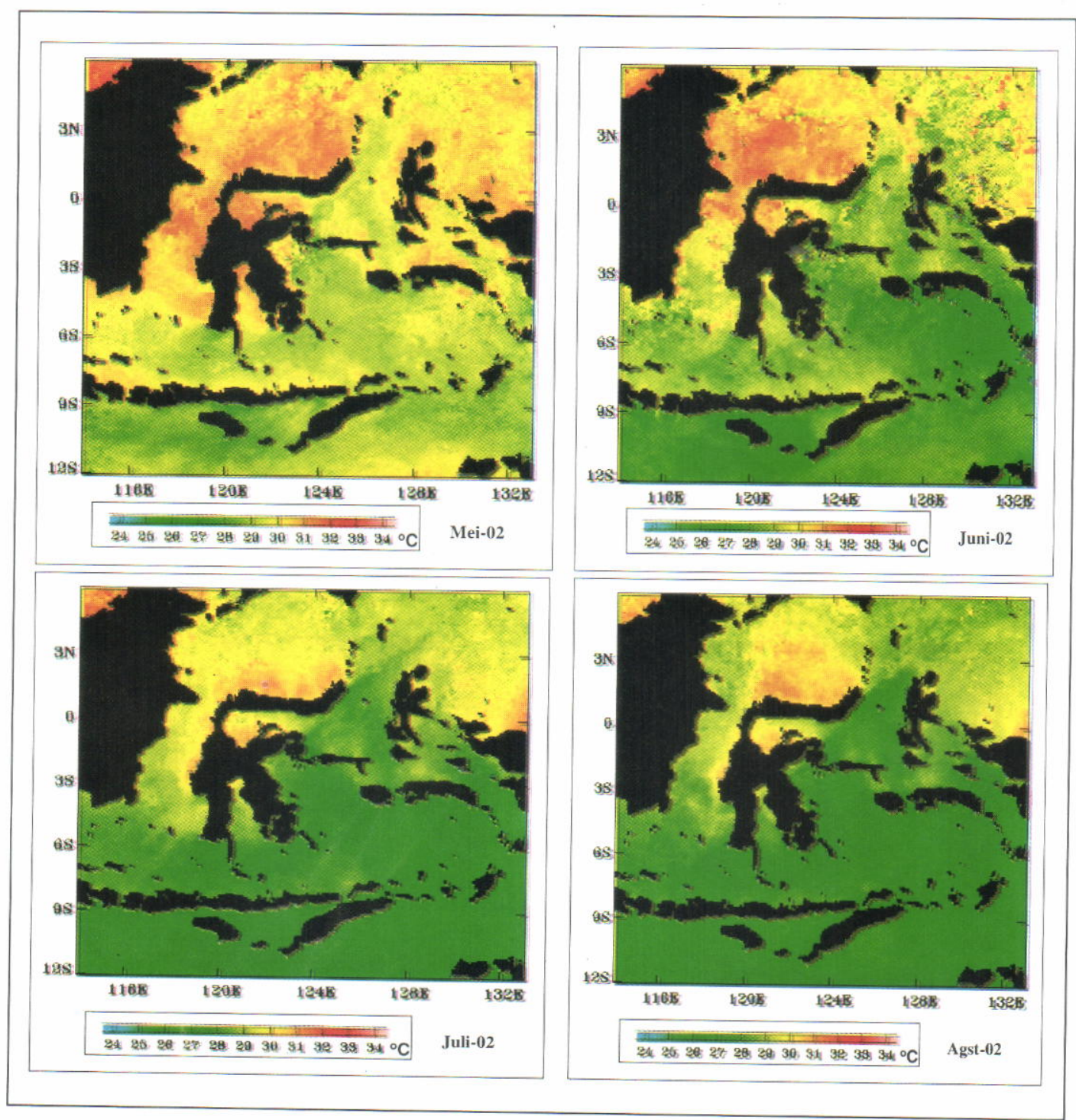




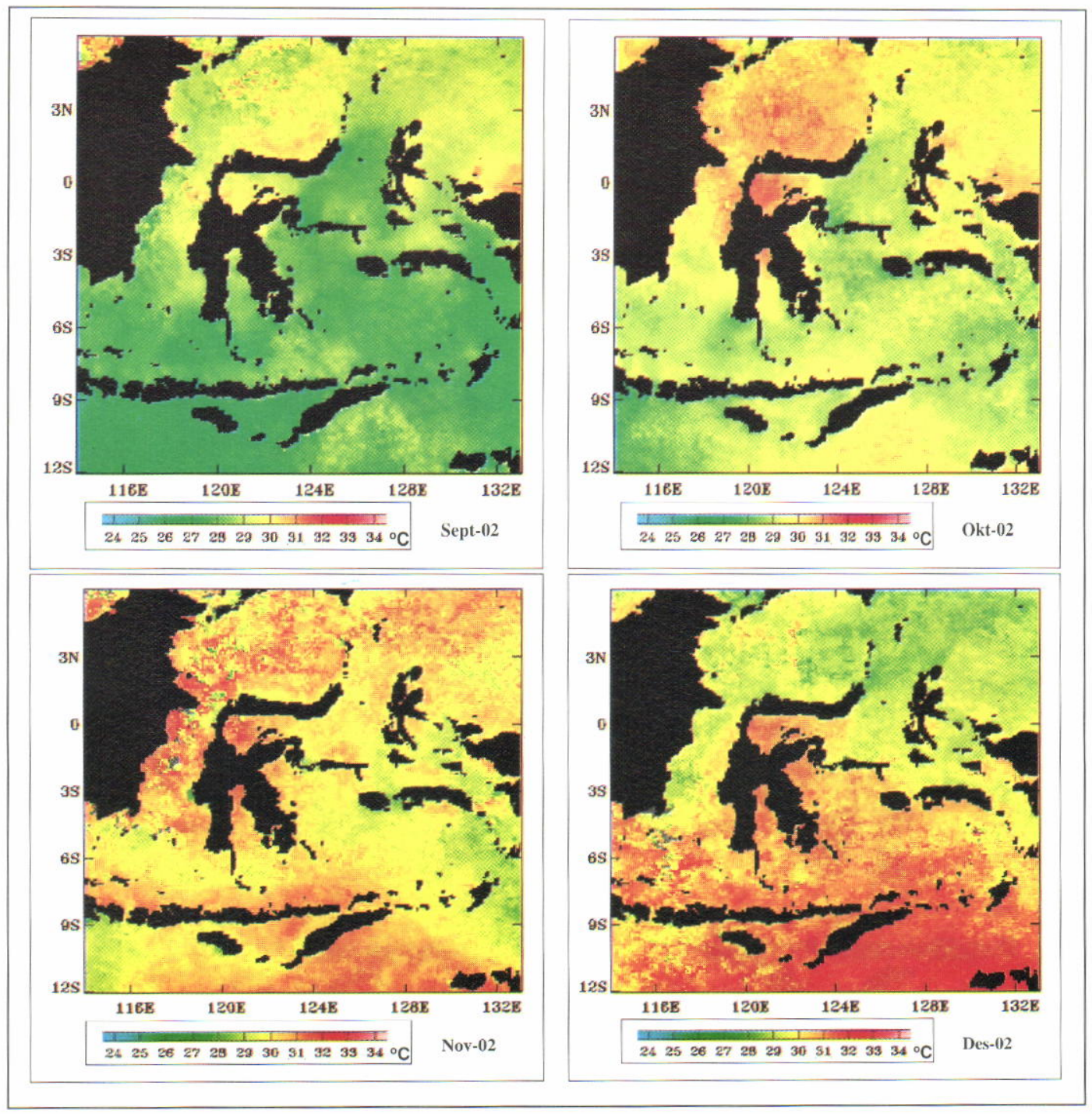




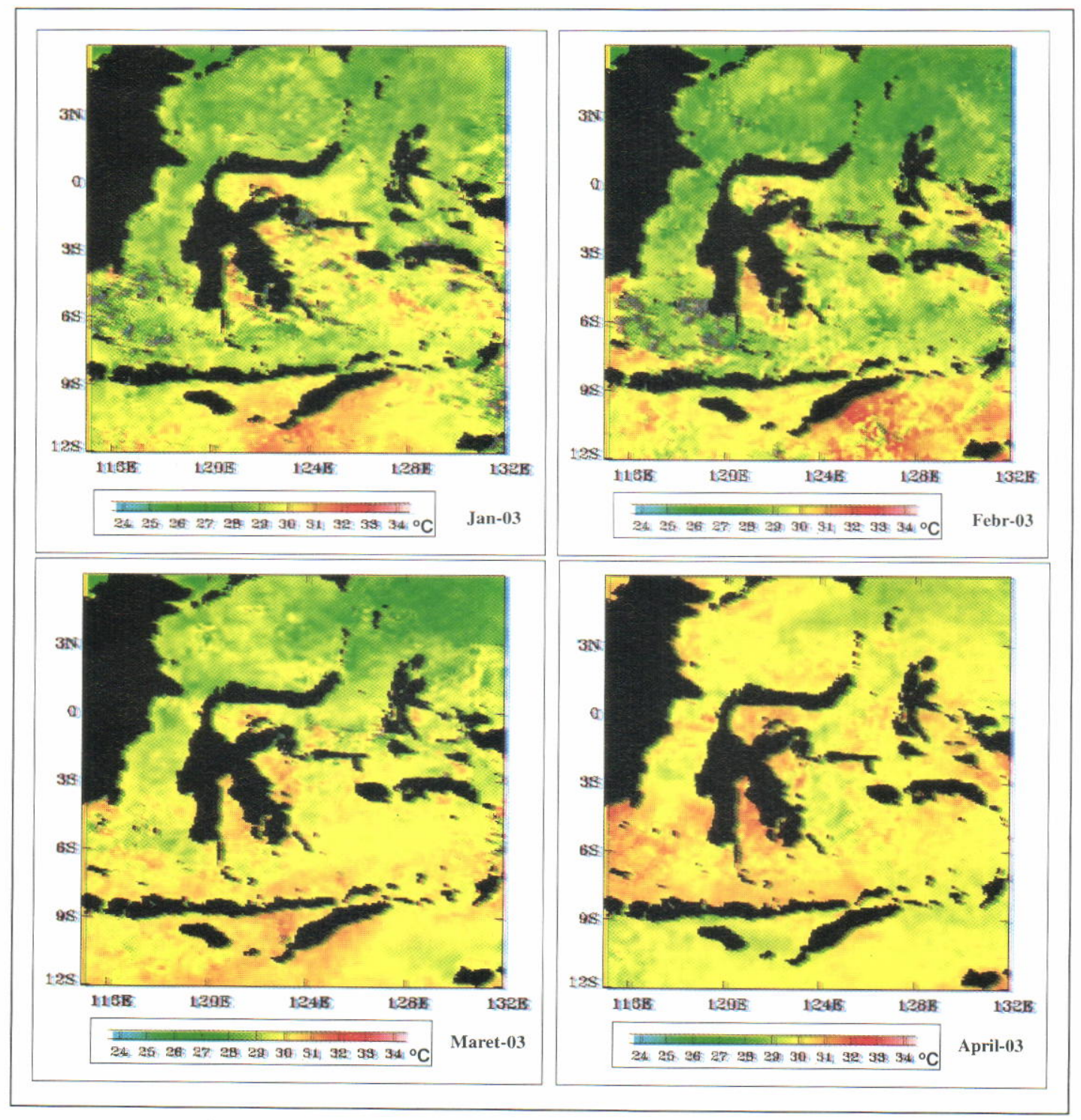




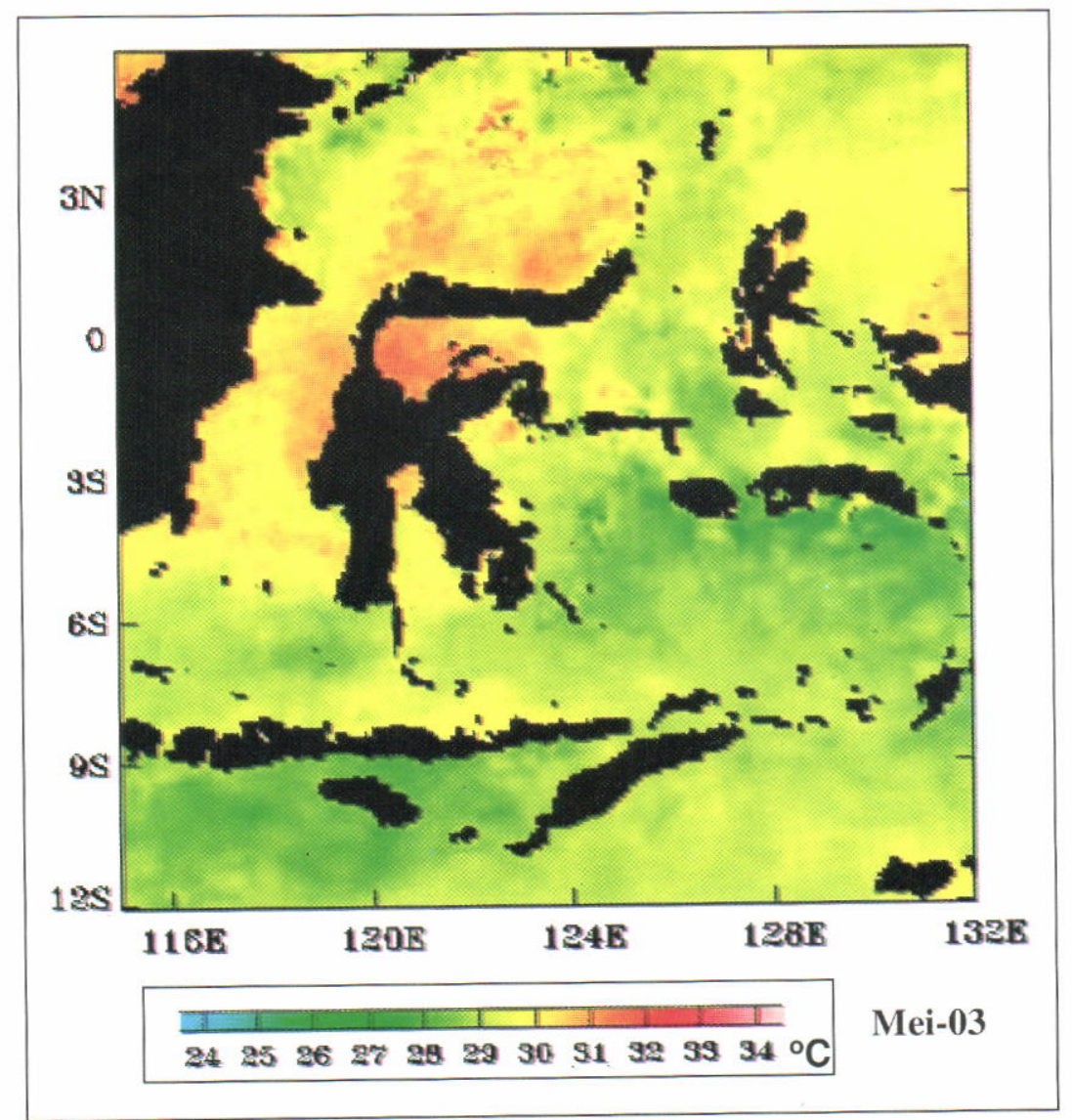


